\title{
EL ASCENSO AL CONOCIMIENTO A TRAVÉS DE PRIMERO SUEÑO DE SOR JUANA INÉS DE LA CRUZ
}

\author{
Marta González de D.* \\ Josefina Pizano**
}

\section{Resumen}

Luego de una presentación, en la primera parte, de algunos aspectos significativos de la vida y la figura de sor Juana Inés de la Cruz, buscamos, en la segunda parte, destacar su producción lírica, haciendo énfasis particular en el carácter barroco de su poesía. Analizamos los primeros versos del poema Primero sueño, y presentamos una visión de conjunto de este importante poema, el más significativo de la autora mexicana.

\section{Palabras clave}

Sor Juana Inés de la Cruz, barroco, siglo XVII, poesía.

\section{Abstract}

After a presentation of some of the outstanding deeds in the life of Juana Inés de la Cruz, in the first part, we pretend, in the second part, stand out her lyrical production, emphasizing particularly the baroque character or her poetry. We analyse the first few lines of the poem Primero sueño, and we present a global view of this important poem, the most significant one of the Mexican writer.

\section{Key words}

Sor Juana Inés de la Cruz, baroque, XVIIth century, poetry.

\footnotetext{
* Docente de tiempo completo de la Facultad de Filosofía de la Universidad Santo Tomás, Bogotá.

** Estudiante de la maestría en literatura de la Universidad de los Andes, Bogotá.
} 


\section{Para un perfil de sor Juana Inés de la Cruz}

La biografía de sor Juana Inés de la Cruz proviene de dos fuentes principales: el conocido documento autobiográfico que la religiosa poeta envió al obispo de Puebla el 1 de mayo de 1691, cuatro años antes de su muerte, conocido con el nombre de Respuesta a sor Filotea de la Cruz, y el esbozo biográfico escrito por el padre Diego Calleja, jesuita amigo de la monja, en el tercer tomo de su obra Fama y obras póstumas. Otros datos se apoyan en documentos encontrados en el Convento de las Jerónimas, así como en diversos archivos y bibliotecas. Estos últimos ayudan a aclarar y a perfilar la vida de esta mujer, cuya obra constituyó un feliz acontecimiento para las letras mejicanas del siglo XVII. Sin embargo, quedan aún por dilucidar algunos momentos especiales de su vida, en particular la fecha de su nacimiento, su entrada al convento y algunos acontecimientos que precedieron a su muerte. Aunque el padre Calleja reunió una gran cantidad de informes con detalles minuciosos sobre la vida de la poetisa, dos grandes enigmas no han podido esclarecerse aún: las razones que la movieron a profesar, y las que, hacia el final de su vida, la llevaron a renunciar a las letras.

\subsection{La niña campesina mexicana}

A decir de varios críticos, la fecha de nacimiento de Juana Ramírez de Asbaje, así se nombraba ella misma, no está del todo clara. Según Calleja, su biógrafo jesuita, Juana nació el 12 de noviembre de 1651 en San Miguel Nepantla, una alquería en las faldas del Popocatepetl. Su madre, criolla, doña Isabel Ramírez de Santillana, dirigía aquella estancia a cuatro leguas del pueblo de Amecameca, en el límite sur del Estado de México. Su padre fue don Pedro Manuel de Asbaje y Vargas Machuca, guipuzcoano, de Vergara. Ni los biógrafos de la monja, ni ella misma, dejarán constancia alguna de la existencia de este caballero español.

A propósito de la exactitud de la fecha de nacimiento de sor Juana, otro de sus biógrafos, Guillermo Ramírez España, da por sentado el siguiente dato: "en el archivo de la Parroquia de Chimalhuacán descubrieron un acta de bautismo correspondiente a una niña Inés "hija de la Iglesia", o sea hija natural, que fue apadrinada por dos hermanos de Doña Isabel Ramírez el 2 de diciembre de 1648”'. El hecho de ser una unión ilegal no fue motivo que intimidara a la madre de Juana. "La ortodoxia sexual en estos tiempos era mucho menos rigurosa que la ortodoxia religiosa. Nuestras ideas acerca de la moral en el siglo XVII deben ser modificadas”, comenta Octavio Paz en el capítulo consagrado a la familia materna de sor Juana ${ }^{2}$. En efecto, las costumbres de la sociedad mejicana de esta época eran más permisivas y aceptaban fácilmente la existencia de hijos naturales. Las mujeres, durante estos años de conquista, gozaban de mucha libertad, situación que contrastaba con su extrema religiosidad. Los conquistadores se maravillaban frente a la belleza exótica de las mujeres del lugar, frente al espectáculo de una naturaleza exuberante y la magnanimidad del clima, que favorecía encuentros festivos, menos sujetos al formalismo que imponían las relaciones interpersonales en países marcados por el ritmo de las estaciones.

Respecto a la vida familiar de Juana Inés, se sabe que era la menor de tres hermanas, a las

1 MERLO, Juan Carlos “Estudio preliminar”. En: Obras escogidas. Por Juana Inés de la Cruz. Edición y selección, Juan Carlos Melo. Barcelona: Bruguera, 1968, p. 14.

2 PAZ, Octavio. Sor Juana Inés de la Cruz o las trampas de la fe. Barcelona: Seix Barral, 1982, p. 101. 
que su madre había criado dentro de un estricto cumplimiento de sus deberes, una responsabilidad a toda prueba, y con las libertades que la vida del campo proporcionaba. El compartir sus años de infancia y adolescencia en la estancia familiar bajo la mirada de una mujer de recia personalidad, formó en Juana un carácter esforzado y a prueba de todos los avatares, tanto económicos como sociales. Su madre, doña Isabel Ramírez, manejaba la hacienda acompañada de sus hijas, cuestión que exigía un gran temple de carácter, así como de vigor físico, pues el hacendado no era únicamente el dueño de la tierra, los animales y los instrumentos de labranza, sino el jefe de una comunidad. En esa familia de "varonas", Juana Inés no fue la excepción, dice Octavio $\mathrm{Paz}^{3}$.

Otros datos y detalles de su formación y de su precocidad infantil aparecen consignados en la Respuesta a sor Filotea de la Cruz. En este escrito nos cuenta hechos que hablan de su genialidad como "niña prodigio". A los tres años aprendió a leer, aprovechando que su madre enviaba a su hermana mayor a que la instruyesen en una de las que llamaban “Amigas", es decir, escuelas de pueblos vecinos: "me encendí yo de manera en el deseo de saber leer, que engañando, a mi parecer, a la maestra, la dije que mi madre ordenaba me diese lección”4. Y así, con gran admiración de doña Isabel, la niña se defendía en las artes de la lectura. Su formación se fue acrecentando, y dos años más tarde ya poseía conocimientos de escritura y de labores que se consideraban propias de su sexo. Su inclinación por el conocimiento se manifestó desde muy joven y, aprovechando la biblioteca de su abuelo materno, se dedicó a una formación autodidacta. Críticas y castigos recibió la niña por su actitud osada. Sin hacer caso a los mayores, continuó leyendo y apasionándose por las letras. El bachiller Martín de Olivas le proporcionó algunas clases de gramática latina, y a partir de allí desarrolló su insaciable habilidad para leer y traducir los clásicos latinos, y componer versos. De aquí en adelante, su formación, sus lecturas y su producción no se detendrían. A imitación de Horacio, Virgilio y Ovidio, y de Góngora y Garcilaso, sus autores preferidos, sus composiciones poéticas irán creciendo en cantidad y calidad.

\subsection{Vida en la capital}

El desplazamiento a la capital, con el consentimiento de su madre, se va a constituir en un factor altamente favorable para su formación intelectual, pero sobre todo para sus relaciones con la Corte virreinal. Pocos años transcurrieron de su estadía en la capital, en casa de sus parientes, cuando, por iniciativa de su tío, la joven fue presentada a los marqueses de Mancera, don Antonio Sebastián de Toledo Molina y Salazar y su esposa, doña Leonor Carreto, ambos personajes de gran cultura e inclinados al cultivo de las letras. La marquesa quedó muy impresionada con la presencia de la joven, y muy pronto fue admitida en el Palacio Real con el título de “muy querida de la señora virreina”. Los vínculos que se establecieron entre las dos fueron muy estrechos, porque las unía su amor a la literatura. Juana Inés aprovechó este paso por el Palacio para nutrirse de lecturas a las cuales no había podido acceder mientras vivía con sus tíos. La época en la Corte fue definitiva para su formación literaria y humanística. Sus dotes intelectuales fueron conocidas y ponderadas por los sabios y teólogos, matemáticos y artistas del momento, como lo atestigua el certamen académico al que fue sometida la joven quinceañera. La Corte comentaba con asombro y satisfacción

\footnotetext{
Ibíd., p. 101.

4 Citado por: MERLO, Op. Cit., p. 15.
} 
su gran sabiduría, y las respuestas ofrecidas sobre muy variados temas, con precisión y desenvoltura, ratificaron que Juana era un caso excepcional de madurez académica y superioridad intelectual. Esta presentación le valió los mejores comentarios en los círculos cortesanos, que con frecuencia la requerían para celebrar con versos acontecimientos sociales e históricos.

\subsection{De la Corte al convento}

La joven Juana Inés, en su paso por la Corte, tuvo oportunidad de relacionarse con el alto mundo virreinal, y su presencia en Palacio causó admiración, no sólo por su inteligencia, que la tenía en demasía, sino por su belleza, su naturalidad y su arte de conversar. Estos atributos le abrieron las puertas de la sociedad virreinal. A los 19 años, cuando su saber y su ingenio habían conquistado la admiración de los doctos, decide entrar al Convento de San José de las Carmelitas Descalzas, el que abandonaría tres meses después alegando la severidad de la regla. Esta situación, que podría haberla desanimado en su deseo de consagrarse como religiosa, más bien la confirmó en su convicción: un año más tarde hizo profesión definitiva, esta vez en el convento San Jerónimo, bajo unas normas menos rigurosas. Los motivos reales que la impulsaron a la vida conventual son desconocidos. Aunque su éxito en la Corte le auguraba un brillante porvenir social, es de suponer que su opción por el claustro le brindara una mayor libertad para el desarrollo de sus labores intelectuales.

Se habla de un sinnúmero de admiradores que, atraídos por el encanto de la joven, la requerían de amores, y en especial uno llamado Fabio. Este galán, que se había acer- cado a Juana con intenciones no muy claras, fue muy pronto rechazado, y la desilusión que provocó este incidente, según dice $\mathrm{Ca}$ lleja, aceleró su entrada al convento. El matrimonio entre ellos no parecía posible, pues, según comenta Octavio $\mathrm{Paz}^{5}$, las relaciones que se convertían en matrimonio se arreglaban entre las familias, y en los enlaces, eran determinantes no la voluntad de los desposados sino las consideraciones sociales y materiales. Este no era el caso de Juana, ya que no disponía de dote, y su familia, al no estar casados sus padres, carecía de toda figuración. Persisten muchas conjeturas alrededor de su amistad con Fabio, y algunos llegan a preguntarse si existió o no tal personaje, pero ello no nos impide hablar de admiradores que, prendados de las cualidades de la joven, la preferían a otras. Se sabe de varios poemas que corresponden a esa época de su vida, entre los cuales cabe destacar aquel soneto que dice:

Que no me quiera Fabio al verse amado, es dolor sin igual en mí sentido; mas que me quiera Silvio, aborrecido, es menor mal, mas no menos enfado.

¿Qué sufrimiento no estará cansado si siempre le resuenan al oído tras la vana arrogancia de un querido el cansado gemir de un desdeñado?

Si de Silvio me cansa el rendimiento, a Fabio canso con estar rendida; si de éste busco el agradecimiento, a mi me busca el otro agradecida; por activa y pasiva es mi tormento, pues padezco en querer y en ser querida ${ }^{6}$.

PAZ, Op.Cit., p. 144.

6 DE LA CRUZ, Juana Inés. Obras selectas I-II. Selección y prólogo de Marco Glantz. Cronología y bibliografía de María Dolores Bravo. Caracas: Biblioteca Ayacucho, 1994, p. I, 9. 
$\mathrm{O}$ aquel otro que dice:

Feliciano me adora y le aborrezco;

Lisardo me aborrece y yo le adoro; por quien no me apetece ingrato, lloro, y al que me llora tierno, no apetezco.

A quien más me desdora, el alma ofrezco; a quien me ofrece víctimas, desdoro; desprecio al que enriquece mi decoro, y al que le hace desprecios, enriquezco.

Si con mi ofensa al uno reconvengo, me reconviene el otro a mí, ofendido; y a padecer de todos modos vengo, pues ambos atormentan mi sentido: aquéste, con pedir lo que no tengo; y aquél, con no tener lo que le pido ${ }^{7}$.

Este juego de contrarios en que están escritos estos versos, de auténtico sabor barroco, se irá afinando cada vez más hasta llegar a emular a Góngora en sus formulaciones conceptistas. Si bien es cierto que la vida social le exigía dedicación, su pensamiento ya estaba tejiendo estrategias para ingresar a las Jerónimas.

Una vez que ingresa al nuevo convento, Juana se va compenetrando con la vida religiosa y con sus obligaciones como monja. Sus actividades en el coro constituyeron parte de sus responsabilidades en la comunidad, y también ocupó el cargo de archivista contadora. En más de una ocasión sus hermanas la postularon como abadesa, cargo que no aceptó, arguyendo que esta actividad le quitaba tiempo precioso para su producción intelectual. A pesar de sus ocupaciones conventuales, sor Juana lograba robarle horas a la noche para componer sus obras poé- ticas. De hecho, como ella misma lo confiesa, sus versos se produjeron al calor de las luces nocturnas, recluida en su celda y lejos del ruido del convento. Dicen los biógrafos que la monja, durante los primeros años de su vida religiosa, enfermó gravemente de tifus o "tabardillo", como lo llama ella repetidas veces en sus poemas. No obstante, a pesar de estos quebrantos de salud, su producción no cesaba. Su fama crecía, tanto en Nueva España, como en la Península.

Es importante señalar que para la época, 1672, el Convento era el centro de una intensa actividad intelectual y artística. Allí se daban cita los marqueses de Mancera, el marqués de la Laguna y su esposa, para platicar con sor Juana. Otro visitante habitual del convento era Carlos de Sigüenza, familiar del ilustre cordobés, el poeta Góngora. Hombres doctos y sobresalientes de esta época se reunían en el locutorio atraídos por la fama de la poetisa monja. Su actitud de mujer en un mundo intelectual dominado por hombres no era concebible. La religiosa era el blanco de críticas de curas confesores, obispos, superioras y abadesas que, envidiosos de su sabiduría y de su amor a la ciencia, la exponían a comentarios hirientes. No era comprensible que una mujer, escritora y poetisa de renombre, manejara el medio intelectual. Sin embargo, sor Juana tenía muchos admiradores. Los marqueses de Mancera fueron sus grandes benefactores y ellos la protegieron mientras duró su gobierno en México. A ellos dedicó innumerables composiciones poéticas. A doña Leonor Carreto, Marquesa de Mancera y esposa del virrey, a quien se refiere con el nombre de Laura, le dedicó el siguiente soneto con ocasión de una enfermedad y posterior convalecencia, atribuyendo su mejoría al amor que ella le profesaba:

7 Ibíd., p. I, 11. 
En la vida que siempre tuya fue, Laura divina y siempre lo será, la Parca fiera, que en seguirme da, quiso asentar por triunfo el mortal pie.

Yo de su atrevimiento me admiré: que si debajo de su imperio está, tener poder no puede en ella ya, pues del suyo contigo me libré. Para cortar hilo que no hiló, La tijera mortal abierta vi.

¡Ay, Parca fiera!, dije entonces yo; mira que sola Laura manda aquí. Ella, corrida, al punto se apartó, $Y$ dejóme morir sólo por $t i^{8}$.

El afecto que sentía sor Juana por la virreina era recíproco, al punto de que, al ser recibida en Palacio, se le otorgó el título de "muy querida de la señora virreina”. Una vez instalada en la Corte, la amistad llegó a ser tan grande que, como nos cuenta Callejas, la virreina "parece no podía vivir un instante sin su Juana Inés, y ella no perdía por eso el tiempo a su estudio"'.

A falta de una composición poética elogiando al marqués de Mancera, hemos seleccionado aquella dedicada al conde de Paredes, quien, junto con su esposa María Luisa, vivieron muy de cerca la vida del Convento y fueron grandes benefactores de sor Juana. En estos versos, la religiosa saluda al Marqués, a quien no había podido expresar sus parabienes en el momento apropiado. Era muy frecuente en esta época una cortesía refinada frente a los superiores, y más aún tratándose de la autoridad principal:

Si daros los buenos años, Señor, que logréis felices, en las Vísperas no pude, recibidlos en Matines.

Nocturna, más no funesta, de noche mi pluma escribe, pues para dar alabanzas hora de Laudes elige. (...)

Gocéis los años más largos que esperanza de infelice, y más gustosos que el mismo la ajena dicha concibe.(...)

Vivid, y vivid discreto, que es sólo vivir felice: que dura, y no vive, quien no sabe apreciar que vive $(. . .)^{10}$.

Entre romances, endechas, redondillas, sonetos y villancicos, su pluma se recreaba en los más variados temas: el amor, los celos, lo religioso y lo teológico, sin olvidar aquellos poemas de circunstancia para celebrar acontecimientos sociales. Esta producción de sor Juana, volcada hacia un refinamiento conceptual extremo y una defensa del saber, le ocasionaron más de un problema. Aunado a esto, su defensa a favor de la mujer y el derecho a una formación intelectual del sexo femenino, hará que sus enemigos le cierren las posibilidades de escribir. No obstante estas dificultades, ella permanecerá activa y luchadora para defender sus derechos.

La aparición del jesuita Atanasio Kircher (1601-1680) en la vida intelectual de la religiosa es una revelación. Este hombre científico y gran conocedor de temas astrológicos, astronómicos, cabalísticos y mitológicos, responde, por su formación humanista, al hombre barroco del momento, fiel heredero

\footnotetext{
Ibíd., p. I, 47.

Ibíd., p. II, 569.

Ibíd., p. I, 57.
} 
del Renacimiento. La obra de Kircher, de manera sorprendente, llega al convento. Sor Juana se nutre de estas lecturas que van a causar en ella una gran fascinación. Era lo que esperaba: poder verter en versos el conocimiento que iba adquiriendo a través de su formación. Resulta llamativo que esta monja de clausura pudiera conocer toda la información científica que circulaba en aquellos tiempos, y que estuviera al día en el manejo literario del verso y de la prosa.

\section{El poema Primero sueño}

Entre su obra lírica sobresale el extenso poema titulado Primero sueño, que, al parecer de los comentaristas, constituye la obra más sobresaliente de su producción, no sólo por su belleza literaria, sino por la amplitud de los temas que maneja, la profundidad de sus reflexiones, y la defensa que hace de la mujer para que se la considere capaz de tomar parte activa en la construcción del conocimiento. Comprender el poema exige una lectura atenta y rigurosa, y es necesario contar con no pocas indicaciones que le permitan al lector orientarse dentro del tejido densamente barroco de imágenes mitológicas, figuras literarias, alusiones a sus contemporáneos y, en particular, el retorcido hipérbaton de sus construcciones. Todo ello teniendo como modelo la obra de Góngora, a quien consideraba su maestro.

Escrito alrededor de 1690, en pleno barroco, este texto enigmático y atravesado de referencias científicas, mitológicas, astronómicas y por supuesto literarias, es la aventura intelectual de mayor vuelo de la monja Juana Inés de la Cruz. En él, parafraseando el poema de Góngora Las soledades, la religiosa mexicana da muestras de una prodigiosa capacidad creadora. Si bien en ambos poemas el tema central es un viaje de hondas reminiscencias homéricas, para el español se trata del viaje de la vida en busca de la trascendencia, mientras que la monja nos narra un viaje en sueño hacia el conocimiento. Ella, como mujer, se halla obsesionada con la posibilidad de participar en ese mundo intelectual restringido a los hombres, mundo que otorga poder político y ofrece las mayores satisfacciones personales. Consciente de su capacidad intelectual, se considera llamada a desarrollar sus conocimientos más allá de todo límite, penetrando los insondables misterios del universo.

Tal como lo menciona Octavio Paz, en este poema sor Juana elabora la imagen del sueño, pero logra romper esa antigua tradición del viaje del alma, porque en él "no aparece ningún abuelo muerto, ningún Pimandro, ningún Virgilio o Beatriz, ningún Cosmiel. Así pues, el poema de sor Juana prolonga la antigua tradición del viaje del alma, pero, en un punto esencial, la quebranta”. Se trata, nos dice, de "algo más que una simple anomalía literaria. Y es algo distinto: es un signo de los tiempos. Algo acaba en este poema y algo comienza" ${ }^{11}$. Su construcción gira en torno a la peregrinación del alma de sor Juana por las esferas supralunares, mientras su cuerpo duerme. Durante el sueño, deja el mundo terrenal y penetra en las regiones oníricas. Esta dualidad entre cuerpo y alma, como dos entidades independientes, proviene de la tradición platónica, reformulada luego por Aristóteles y asumida en gran medida por la escolástica. Ahora bien, la composición del poema dista mucho de la forma como el sueño fue interpretado por sus antecesores. Al decir de Octavio Paz, "en lo que toca al asunto $\mathrm{y}$ al fondo del poema, no hay en toda la literatura y la poesía de los siglos XVI y XVII nada que se parezca al 'Primero sueño'”'12.

PAZ. Op. Cit., pp. 481-482.

12 Ibíd., p. 474. 


\subsection{Hipérbaton y metáfora como figuras que expresan el barroco}

A la manera de su maestro Góngora, sor Juana compone Primero sueño haciendo uso de las figuras literarias de mayor agrado para los conceptistas: el hipérbaton y la metáfora. Si la primera reorganiza la construcción gramatical para adecuarla a las exigencias poéticas, la metáfora, por su parte, realza el significado de una idea mediante otra, con la cual guarda semejanza o analogía.

El poema irrumpe con los siguientes versos:

Piramidal, funesta, de la tierra nacida sombra, al Cielo encaminaba

de vanos obeliscos punta altiva, escalar pretendiendo las Estrellas;

si bien sus luces bellas,

-exentas siempre, siempre rutilantes-

la tenebrosa guerra

que con negros vapores le intimaba

la pavorosa sombra fugitiva,

burlaban tan distantes,

que su atezado seño

al superior convexo aun no llegaba

del orbe de la Diosa

que tres veces hermosa

con tres hermosos rostros ser ostenta,

quedando sólo dueño

del aire que empañaba

con el aliento denso que exhalaba;

$y$ en la quietud contenta

de imperio silencioso,

sumisas sólo voces consentía

de las nocturnas aves,

tan obscuras, tan graves,

que aun el silencio no se interrumpía.
Con la ayuda de Octavio Paz y de la Prosificación del sueño, elaborada por Georgina Sabat ${ }^{13}$, tratemos de entender el cúmulo de imágenes que en forma atropellada dan inicio al poema. Se trata de describir el ascenso del alma que, desde las tinieblas, busca llegar a la luz del conocimiento. La pirámide representa este ascenso del alma al infinito, pretendiendo alcanzar las estrellas. Éstas, sin embargo, se hallan tan lejanas y "exentas", como dice la monja, es decir, por completo libres y rutilantes, que la amenaza que significaría para ellas el ascenso del alma se queda en el camino, sin llegar siquiera al primer círculo formado por la luna y su rotación alrededor de la tierra.

La imagen de la luna es representada, a su vez, por una Diosa, "que tres veces hermosa/ con tres hermosos rostros ser ostenta”, es decir, figurada por las imágenes de Diana, Hécate y Proserpina. El oscuro rostro del alma ("atezado seño [sic]") permanece entonces en medio de la tiniebla, "quedando sólo dueño/ del aire que empañaba/ con el aliento denso que exhalaba”. Se trata de una aglomeración de imágenes que evocan la oscuridad, la ignorancia y el silencio. En esta oscuridad sólo se escuchan los graznidos de las aves nocturnas, y el poema subraya el silencio, señalando, en una figura de gran fuerza por su misma contradicción, que esas voces eran "tan oscuras, tan graves,/ que aun el silencio no se interrumpía”.

La construcción de las frases se retuerce como en espirales, forzando el hipérbaton y acumulando las metáforas, que se hacen presentes desde el primer verso. Así continuará, otorgándole al lenguaje una fuerza en su mismo entreveramiento, y obligando al lector a prestar una particular atención al sentido, tanto por el rebuscado orden de sus ex-

13 Ver: PAZ, Op. Cit., p. 469 ss.; De la Cruz, Op. Cit., p. II, 111 ss. 
presiones, como por la riqueza y abundancia de las imágenes.

Ahora bien, la construcción cifrada de este poema obedece a dos factores. Por una parte, se ajusta a los cánones barrocos, que exigían la formulación de conceptos refinados en donde se entremezclaban la teología, la mitología, la ciencia, la astronomía, la astrología, etc., y, por otra, se enfrenta a lectores agudos y perspicaces que pudieran leer detrás de la palabra escrita todo un mensaje lleno de referencias y alegorías. Se trataba de un juego de seducción en el que la autora parece esconderse para despertar la curiosidad de sus lectores, quienes podrán así experimentar más intensamente lo inesperado del descubrimiento.

Tal como observa Octavio Paz en su ensayo sobre el poema, la monja tituló su escrito, en una primera versión, El sueño, y en la edición de 1692 el título se alargó: Primero sueño que así intituló y compuso la madre Juana, imitando a Góngora. Las semejanzas con Las soledades del escritor español son sensibles, aunque las diferencias son igualmente notables. En sor Juana evidenciamos un lenguaje marcadamente intelectual, mientras que el de Góngora apela sobre todo a los sentidos. Si el mundo del poeta español estalla en colores luminosos, la mejicana, en cambio, busca elevarse al campo del concepto. Se trata en ambos casos de silvas, estrofas que combinan versos de siete y de once sílabas, lo que permite el desarrollo de múltiples temas sin sujeciones estilísticas. Mientras que el lenguaje de la religiosa mejicana es con frecuencia concentrado y hermético, Góngora, en cambio, utiliza el idioma como un juego maravilloso de matices. En ella triunfa el claroscuro del barroco; de hecho su composición se sitúa en un tiempo oscuro, la noche, momento supremo de su viaje espiritual, y el alma misma aparece como una negra sombra que busca escalar hasta las estrellas. Góngora, en cambio, se sitúa en un paisaje exterior que recorre, como el viajero Odiseo, en busca de su encuentro con la naturaleza. El texto de sor Juana hace gala de intelectualismo, no carente de gran sensibilidad, y los conceptos que elabora nos remiten a un universo de conocimientos inusuales para una religiosa del siglo XVII en Méjico.

\subsection{Construcción del poema}

Su biógrafo, el padre Diego Calleja, nos cuenta con las siguientes palabras de la monja la génesis del poema: "Siendo noche me dormí; soñé que de una vez quería comprender todas las cosas de que el Universo se compone; no pude ni aun divisar por sus categorías ni aun sólo un individuo. Desengañada, amaneció y desperté»14.

El entramado mitológico, científico, religioso, teológico y literario del poema es un andamiaje soberbio que, como una figura geométrica compuesta de muchos ángulos, se descompone a su vez en otras figuras de iguales formas para producir un efecto óptico caleidoscópico. En este brillo de luces intensas aparecen las alusiones mitológicas. Nictimene, por ejemplo, figura de la oscuridad, que puede leerse como una imagen de la noche, momento en que la monja escribe, aunque su acepción primera está centrada en la imagen de la trasgresión que mencionaremos más adelante. Minerva, diosa de la sabiduría, conocida también como Palas Atenea, cuya aparición en los versos de sor Juana nos habla del conocimiento al que ella aspira. Pero, además de lo mitológico, y haciendo uso expreso de él, la monja trae a colación el tema femenino. Su propósito expreso es la reivindicación de la mujer y la valoración de sí misma. La vida de esta reli-

14 DE LA CRUZ, Juana Inés. Obras escogidas. Edición y selección de Juan Carlos Melo. Barcelona: Bruguera, 1968, p. 258. 
giosa fue una lucha permanente, empeñada tras los bastidores, para alcanzar el saber y expresarlo en la poesía, buscando la libertad de pensamiento, y en defensa de su derecho a la educación y a la cultura.

Los mitos utilizados en la primera parte de esta composición, del verso inicial hasta el 90 , tienen nombre de mujer. Se habla del orbe de la Diosa, referencia a Diana, diosa de las tres caras y divinidad de la naturaleza en sus manifestaciones más indómitas y feroces. Ella ejercía un poderío absoluto en su reino, $y$, si nos atenemos a su figura, la diosa femenina reinaba en sus dominios luchando incansable para defenderse de sus enemigos. Ya mencionado anteriormente, el mito de Nictimene alude a la persecución de que fue objeto esta joven por sus relaciones incestuosas: por su pecado, debe huir. En Primero sueño, la noche, Nictimene, es para sor Juana el momento propicio para adentrarse en el conocimiento y dedicarse a la escritura, huyendo de los ruidos del convento. La Engañosa, la Encantadora Alcione, también hace parte de ese grupo de deidades que, al transgredir la norma, sufren el castigo de las divinidades del Olimpo. Existe así todo un juego de imágenes que apuntan a presentar el acceso a la sabiduría como una trasgresión que, en el caso de la mujer, tiene un sentido aún más fuerte: si todo intento de saber y de abarcar el universo es una forma de rebelión del hombre contra los arcanos divinos, cuando ese intento lo realiza la mujer se vuelve objeto de castigo.

Los comentaristas han buscado desentrañar la estructura del poema y han ofrecido diversas interpretaciones del mismo. Así, Pfandl lo divide en forma de un altar gótico compuesto de cinco secciones, conformadas por una tabla central y cuatro alas laterales: $1^{\text {a }}$, el hechizo del sueño (hasta el verso 191); $2^{\mathrm{a}}$, la teoría del sueño (hasta el verso 291); $3^{\mathrm{a}}$, la vivencia del sueño (hasta el verso 826); $4^{\mathrm{a}}$, el tránsito del umbral del sueño (hasta el verso 886); $5^{\mathrm{a}}$, el nacimiento del sol (hasta el final). El núcleo central lo conforma la vivencia, donde el alma, ya libre de sus ocupaciones materiales, emprende el vuelo hacia las esferas celestes para recorrer la totalidad del universo. Georgina Sabat, por su parte, propone una división tripartita, compuesta de un prólogo denominado "Noche y sueño del cosmos”, que se extiende del verso 1 al 150. Una segunda parte que lleva por título "El sueño intelectual del hombre", y abarca la mayor parte del poema, desde el verso 151 hasta el 886. Y una tercera parte titulada "Epílogo: triunfo del día”, del verso 887 al 975. La segunda parte, a su vez, se desarrolla en cuatro subdivisiones, cuyos títulos son "El dormir humano", "Intuición neoplatónica”, "Raciocinio neoaristotélico" y "El despertar humano".

\section{Bibliografía}

DE LA CRUZ, Juana Inés, sor. Obras escogidas. Edición y selección, Juan Carlos Merlo. Barcelona: Bruguera, 1968.

Obras selectas I-II. Selección y prólogo de Marco Glantz. Cronología y bibliografía de María Dolores Bravo. Caracas: Biblioteca Ayacucho, 1994.

GLANTZ, Marco. "Prólogo". En: De la Cruz, Obras selectas I-II, pp. XI-XCIII.

MERLO, Juan Carlos. "Estudio preliminar”. En: De la Cruz, Obras escogidas, pp. 13-70.

PAZ, Octavio. Sor Juana Inés de la Cruz o las trampas de la fe. Barcelona: Seix Barral, 1982.

SABAT, Georgina. "Prosificación del sueño”. En: De la Cruz, Obras selectas, p. 111-119. 